Nadine Proske

\title{
Emergent pseudo-coordination in spoken German. A corpus-based exploration
}

https://doi.org/10.1515/gcla-2019-0008

\begin{abstract}
This paper investigates emergent pseudo-coordination in spoken German. In a corpus-based study, seven verbs in the first conjunct are analyzed regarding the degree of semantic bleaching and the development of subjective or aspectual meaning components. Moreover, it is shown that each verb shows distinct tendencies for co-ocurrences, especially with deictic adverbs in the first conjunct and with specific verbs and verb classes in the second conjunct. It is argued that pseudo-coordination is originally motivated by the need for 'chunking' in unplanned speech and that it is still prominently used in this function in German, in contrast to languages in which pseudo-coordination is grammaticalized further.
\end{abstract}

Keywords: pseudo-coordination, motion verbs, posture verbs, grammaticalization, spoken German

\section{Introduction}

In spoken German, one frequently encounters coordinated clauses like (1), which depart from canonical coordination semantically; the first verb is ambiguous between a literal and a bleached meaning, and, independently of this, the verbs of the two coordinated clauses express a single event.

(1) den ANderen tag, kommt meine frEUndin so zu mir und sAcht JA, öh willste was von IHM; [FOLK_E_00256 / T_03 / c363]

'The other day, my friend comes [up to me] to me and says: Well, um, do you want something from him?'

Examples like this correspond to constructions in other languages that have been called pseudo-coordination. This construction has hardly been recognized to exist in German, possibly because it is not as clearly desemanticized or even grammaticalized as in other languages.

Nadine Proske, Leibniz-Institut für Deutsche Sprache (IDS) Mannheim, proske@ids-mannheim.de 
The first goal of the present paper is to show that pseudo-coordination exists as a conventionalized construction in German and, more specifically, that there are several verb-specific constructions with distinct semantic and pragmatic features. The second goal is to explore which of the observed semantic properties may lead to a grammaticalization of the first verbs in directions that have been described for pseudo-coordination in other languages.

The incipient stages and original motivations of this possible development can best be seen in spoken data, as the originally bi-clausal construction has features motivated by the conditions underlying the production and reception of talk-ininteraction (e.g., the necessity for 'information packaging'). It can be hypothesized that the discourse-pragmatic functions will lose import if the subjectification and grammaticalization of frequent verbs in the first conjunct progress.

\section{Pseudo-coordination}

The phenomenon under scrutiny has been described under several different names, depending on the theoretical approach and the language under investigation. It has most often been called pseudo-coordination (e.g., Hesse 2009; Ross 2013), but also hendiadys (Hopper 2002, 2008), V and V construction (Newman and Rice 2008), or coordinated-verb construction (Stefanowitsch 2000). ${ }^{1}$ Independently of the terminological label, its definition encompasses a formal and a semantic part. Formally, we deal with two clauses coordinated by a conjunction meaning 'and' that have the same subject referent that is realized elliptically in the second clause. Semantically, the two verbs occurring in separate clauses code one event, that is, the construction is 'monopredicative' (Hopper 2008: 255). ${ }^{2}$ The first verb is often subject to semantic bleaching and the emergence of aspectual, modal and other subjective meanings and thus to (incipient) grammaticalization. ${ }^{3}$

Pseudo-coordination is cross-linguistically restricted to a specific set of verbs in the first conjunct: ${ }^{4}$ unspecific verbs of motion ('come' and 'go'), verbs of posture

\footnotetext{
1 A bibliography of studies on pseudo-coordination in a wide range of languages is included in Ross (2013).

2 Some authors describe pseudo-coordination as VP coordination. This does not seem appropriate for German because of the low degree of grammaticalization.

3 For the interdependence of grammaticalization and subjectification see e.g. Langacker 1990; Traugott and Dasher 2002: 89ff.

4 This view has been explicitly challenged by Hopper (2002: 170), who shows that verbs not usually regarded as candidates for the first verb in a pseudo-coordination, like turn around and,
} 
and change of posture ('sit (down)', 'stand (up)', 'lie (down)') and some other intransitive verbs (e.g., engl. try), but also the transitive verb meaning 'take'. All of these verbs are well-known sources of grammaticalization in general; they "can be thought of as a semi-closed class encompassing several subgroups which correspond to the cross-linguistically common sources for both light verbs and auxiliaries." (Hilpert and Koops 2008: 245f.) ${ }^{5}$

Determining the degree of grammaticalization or just of the degree of 'monopredicativity', which precedes it, is not always straightforward, especially when working with authentic (spoken) examples; the criteria used in the literature can serve as a reference point nonetheless: If a coordination is monopredicative, its two verbs usually have the same tense, aspect and mood and if there are (temporal) adverbials or negation in the first clause, they have scope over the second verb as well. ${ }^{6}$ In the grammaticalization process, the increasing monopredicativity is also reflected in the gradual reduction of elements occurring between the two verbs and the conjunction: "the more intervening elements occur between the two verbs, the weaker the conceptual union appears to be" (Hilpert and Koops 2008: 245). The reduction of intervening elements pertains to a reduction of arguments (formerly obligatory local or directional complements of motion and posture verbs are elided), a loss of optional individual modifications of the first verb and an increase of object extraction. ${ }^{7}$

It is often claimed in studies on pseudo-coordination in English and the Scandinavian languages that the phenomenon does not exist in German (Hesse 2009; Hopper 2008: 276; Ross 2013: 61). Lehmann (1991: 20f.), however, already mentions the auxiliary-like use of the basic motion verbs kommen ('come') and gehen ('go') in an overview of current grammaticalization phenomena in German, under a different name ('andative' and 'venitive'), and, in the first empirical study to date, Proske (2017) investigates pseudo-coordinated kommen in spoken German.

There are several possible reasons why coordinating constructions containing the most basic motion or posture verbs have been overlooked as candidates

are used with bleached, subjective semantics. In the present paper, the investigation is restricted to the 'classical' candidates.

5 It is a matter of debate whether the first verb of a pseudo-coordination becomes an auxiliary or a light verb in the process of grammaticalization.

6 There are a few linguistic tests for identifying monopredicative examples, which are not always (easily) applicable and cannot be discussed here (see Proske 2017: 188ff.).

7 Object extraction only occurs at a very late stage of grammaticalization, which has not been reached by any German verb and therefore is not relevant for the current study. 
for pseudo-coordination in German. First, due to the relatively free German word order there can be many intervening elements between the two verbs even in clearly monopredicative cases. Second, the first verb in the construction is desemanticized to a lower degree in German than in other languages. Third, 'go' is very prominent cross-linguistically as the first verb in pseudo-coordination and is often the focus of empirical studies on English; in German, however, while gehen ('go') is also used in pseudo-coordination, its deictic counterpart kommen ('come') is the more prominent candidate (see 3.2.1). Fourth, most verbs used in pseudo-coordination in German are accompanied by a directional or local adverbial, which should not be present if the first verb was fully grammaticalized; this adverbial may, however, in many cases be regarded as a grammaticalized verb particle, that is, as part of one variant of the basic motion or posture verb (see 3.2).

The aim of the present study is to offer a first explorative description of seven verbs used in pseudo-coordination in German. The verbs were chosen based on their semantic equivalence to verbs in other languages that are used in pseudocoordination, also considering frequency of occurrence in the corpus that was used..$^{8}$ It will be shown that the formal and semantic-pragmatic range of each of the verbs used in pseudo-coordination is still large, but that for each verb, formally more fixed and semantically less transparent variants exist, which may foreshadow future grammaticalizations.

\section{Emergent pseudo-coordination in spoken German}

\subsection{Data}

The data for the present study come from the Research and Teaching Corpus of Spoken German (Forschungs- und Lehrkorpus Gesprochenes Deutsch, FOLK). ${ }^{9}$ This corpus is designed as a growing reference corpus of current spoken German. It contains spoken interactions in diverse settings, including private, institutional and public interaction types, and seeks to cover all Germanspeaking areas. When the searches for the present study were conducted (release

\footnotetext{
8 The verbs liegen ('lie') and sich legen ('lie down'), for example, are used in pseudo-coordination in other languages, but were not included because no relevant examples could be found in the German corpus.

9 The corpus is available at http://agd.ids-mannheim.de/folk.shtml.
} 
$2.10,2018)$, the corpus contained approximately 229 hours of audio material, that is, 281 transcribed spoken interactions amounting to approximately 2.2 million tokens. The corpus was searched for the lemmas kommen ('come'), gehen ('go'), sitzen ('sit'), stehen ('stand'), sich setzen ('sit down'), sich stellen ('stand up') and nehmen ('take') with und ('and') in the right context (up to 15 tokens to the right). ${ }^{10}$ All examples that these searches yielded were then inspected manually for whether they are potential cases of pseudo-coordination. Included were cases with and without directional or local complement and with bleached as well as transparent but monopredicative semantics. These cases were then analyzed for several features (e.g., occurrence of a directional or local adverbial, pronominal vs. lexical realization of the first verb's arguments, the semantic class of the second verb), which will be discussed in the verb-specific analyses in section 3.2. ${ }^{11}$

The following sections give an overview of the formal and functional range of each of the seven verbs used in pseudo-coordination. It will be pointed out how the observed functions relate to semantic changes commonly going along with the grammaticalization of motion and posture verbs described in the literature. Moreover, it will be briefly discussed which formal features speak in favor of the conventionalization of the constructions under investigation - despite the lack of a clear grammaticalization of the first verbs.

Table 1 gives a preliminary overview of the frequencies of occurrence of the combinations of the specific verbs in the first conjunct (V1) and the semantic classes of the verbs in the second conjunct (V2). The statistical sub-division (e.g., sitzen $+d a$ vs. sitzen $-d a$ ) has a different motivation for each verb, which will become clear in the following sections.

Table 1: Frequency of verbs in the first and second conjunct of pseudo-coordination.

\begin{tabular}{lrlrrrr}
\hline V1 & $\begin{array}{l}\text { frequency } \\
\text { of lemma }\end{array}$ & $\begin{array}{l}\text { used in } \\
\text { pseudo- } \\
\text { coordination }\end{array}$ & $\begin{array}{l}\text { V2: verbs of } \\
\text { communication } \\
\text { (including } \\
\text { sagen) }\end{array}$ & V2: sagen & $\begin{array}{l}\text { V2: activity } \\
\text { verbs }\end{array}$ & $\begin{array}{l}\text { V2: mental, } \\
\text { stative \& } \\
\text { perception } \\
\text { verbs }\end{array}$ \\
\hline kommen & 6946 & 140 & $55(39 \%)$ & $35(25 \%)$ & $65(46 \%)$ & $20(15 \%)$ \\
+ DIR/particle & & 76 & $31(41 \%)$ & $18(24 \%)$ & $27(35 \%)$ & $18(24 \%)$ \\
- DIR/particle & & 64 & $24(38 \%)$ & $17(27 \%)$ & $38(59 \%)$ & $2(3 \%)$ \\
\hline
\end{tabular}

10 For all verbs, prefix-like adverbial particles such as hin, her, rum etc. were included.

11 Not all of the features that were analyzed can systematically be discussed in this paper (e.g., word order and prosodic realization), but will enter into future, more detailed analyses. 
Table 1: (continued)

\begin{tabular}{|c|c|c|c|c|c|c|}
\hline V1 & $\begin{array}{l}\text { frequency } \\
\text { of lemma }\end{array}$ & $\begin{array}{l}\text { used in } \\
\text { pseudo- } \\
\text { coordination }\end{array}$ & $\begin{array}{l}\text { V2: verbs of } \\
\text { communication } \\
\text { (including } \\
\text { sagen) }\end{array}$ & V2: sagen & $\begin{array}{l}\text { V2: activity } \\
\text { verbs }\end{array}$ & $\begin{array}{l}\text { V2: mental, } \\
\text { stative \& } \\
\text { perception } \\
\text { verbs }\end{array}$ \\
\hline gehen & 8220 & 146 & $32(22 \%)$ & $20(14 \%)$ & $86(59 \%)$ & $28(19 \%)$ \\
\hline + DIR/particle & & 99 & 19 (19\%) & $13(13 \%)$ & $60(61 \%)$ & $20(20 \%)$ \\
\hline+ hin/her & & 47 & $13(28 \%)$ & 7 (15\%) & $26(55 \%)$ & $8(17 \%)$ \\
\hline sitzen & 696 & 76 & 11 (14\%) & $3(4 \%)$ & $43(57 \%)$ & 22 (29\%) \\
\hline$+d a$ & & 24 & $2(8 \%)$ & $2(8 \%)$ & $12(50 \%)$ & $10(42 \%)$ \\
\hline$-d a$ & & 52 & 9 (17\%) & $1(2 \%)$ & $31(60 \%)$ & $12(23 \%)$ \\
\hline stehen & 2544 & 44 & $8(18 \%)$ & $4(9 \%)$ & $20(45 \%)$ & $16(36 \%)$ \\
\hline$+d a$ & & 13 & $4(31 \%)$ & $3(23 \%)$ & 5 (38\%) & $4(31 \%)$ \\
\hline$-d a$ & & 31 & $4(13 \%)$ & $1(3 \%)$ & 15 (48\%) & $12(39 \%)$ \\
\hline sich setzen & 562 & 26 & $6(23 \%)$ & $4(15 \%)$ & $15(58 \%)$ & 5 (19\%) \\
\hline+ hin & & 20 & $4(20 \%)$ & $2(10 \%)$ & $13(65 \%)$ & $3(15 \%)$ \\
\hline$-h i n$ & & 6 & $2(33 \%)$ & $2(33 \%)$ & $2(33 \%)$ & $2(33 \%)$ \\
\hline sich stellen & 1001 & 17 & $9(53 \%)$ & $8(47 \%)$ & $6(35 \%)$ & $2(12 \%)$ \\
\hline+ hin & & 12 & $8(67 \%)$ & $8(67 \%)$ & $4(33 \%)$ & $0(0 \%)$ \\
\hline$-h i n$ & & 5 & $1(20 \%)$ & $0(0 \%)$ & $2(40 \%)$ & $2(40 \%)$ \\
\hline nehmen & 2640 & 40 & $0(0 \%)$ & $0(0 \%)$ & 40 (100\%) & $0(0 \%)$ \\
\hline
\end{tabular}

\subsection{Verb-specific analyses}

\subsubsection{Motion verbs: kommen and gehen}

The basic motion verbs kommen ('come') and gehen ('go') are the most frequent ones among the seven verbs investigated in this study, and they are the ones most frequently occurring in pseudo-coordination (see table 1 above). Both verbs show clearly bleached semantics in only around 15 percent of the pseudo-coordinated cases. However, mentioning the motion act is contextually not necessary in all cases, that is, the second verb delivers the contextually relevant propositional meaning, notwithstanding the additional semantic effects of using the first verb, which are discussed below.

The following examples show how kommen is typically used in pseudocoordination. ${ }^{12}$ As in these examples, the directional adverbial is not realized in $57 \%$ of the cases.

12 The transcription of the examples follows GAT 2 (Selting et al. 2009). Accented syllables are marked by upper case, punctuation marks are used to indicate different prosodic contours. 
(2) den sollen se jetz schÖn lAng AUFheben; und von A nach BE räumen; $<<$ lachend > bis ich KOMM und den HOL.> [FOLK_E_00055 / T_07 / c234] 'I want them to keep it [=the passport] for a long time and to put it back and forth a lot until I come and/to get it.'

(3) sie is ja als hausmeisterin dafür verANTwortlich. für die SAchen; also wenn der hAUsverwalter KOMMT und sAgt, ${ }^{\circ} \mathrm{h}$ dis_ $n$ dis PASST nich, dann muss sie HINhalten. [FOLK_E_00055 / T_05 / c496]

'As the caretaker she is responsible for these things. So if the building manager comes [up to her] and says that this and that is not okay she has to account for it.'

(4) der kann ja NIT sache:- daNOCH; =und_e johr spÄter kumm und sAche JA(1.62) musch_s zuRÜCKzahle wenn er geht. [FOLK_E_00004 / T_02 / c354]

'He cannot say afterwards, and come [back] a year later and say: "Well, he'll have to pay it back when he leaves".'

In (2), a student is telling her flatmates about the trouble she had with getting her new passport. The semantics of kommen is not bleached, but mentioning the motion act is not propositionally necessary. Rather, the use of kommen, has the additional semantic effect of highlighting the effort associated with the action denoted by the second verb holen ('get') - while holen only implies the motion event, the use of kommen makes explicit its necessity and the intentional effort of the subject referent. Thus, kommen is used not because of its motion semantics per se, but because intentionality is an obligatory semantic feature of its basic motion semantics (see Di Meola 1994). ${ }^{13}$ Moreover, by using kommen, the event denoted by the second verb is perspectivized from the view of someone located at the goal of the motion event, as kommen is inherently "goal-oriented" (Fillmore 1972). For (2), this means that the event of the student getting her passport is viewed from the perspective of the people working at the office that issues the document.

This monopredicative use of kommen und has been called "purposefocusing" in Proske (2017), as the purpose of the motion event is expressed by the second verb. The V2 can be regarded as the main verb, which is focused (or "foregrounded", Hopper 2002) by the first verb, which is about to lose its main verb status. In general, the V2 are most often verbs of transfer, general

13 As Di Meola (1994) points out, there are other meanings of kommen that specifically do not feature intentionality, for example 'caused motion' (Er kam ins Krankenhaus. 'He was brought to hospital.'). 
activity or communication. Clear cases of semantic bleaching only occur with verbs of communication, which sets them apart as a special subclass. ${ }^{14}$

The purpose of the motion event is a communicative event in 39\% of the cases in the data, which is most frequently expressed by the verb sagen ('say'), as in (3) and (4). While in (3) kommen may or may not refer to an actual movement of the subject referent, in (4) the semantics is clearly bleached. The repair shows that it is the speaker's intention to talk about the communicative event in the first place: The speaker starts with a clause containing only sagen, then abandons this clause and starts a new one containing kommen und sagen. In both (3) and (4) the effect of using kommen is a highlighting of the intentionality of the communicative event; the semantics of sagen is underspecified ('utter'), and kommen 'upgrades' this semantics, that is, the meaning of kommen und sagen refers to the more specific communicative event of 'expressing a concern'.

This semantic specialization and the fact that sagen is the most frequent lexeme occurring as V2 in pseudo-coordination with kommen (see table 1) suggest that this co-occurrence might constitute a (semi-)fixed unit. ${ }^{15}$ What corroborates this hypothesis is the tendency for less intervening elements between these two verbs than between kommen and other second verbs (see the discussion in section 4).

When taking into account the conversational and turn-constructional context, a further tendency can be observed: kommen und sagen is often part of longer, narrative turns and the content put forward by the subject referent is often assessed negatively either by the speaker or a protagonist of the ongoing story.

As the deictic counterpart of kommen, the use of gehen ('go') in pseudocoordination shows several similarities, but also distinct usage patterns: First, the directional adverbial is always realized, ${ }^{16}$ as in (5).

(5) geh zum bÄcker un KAAF eenen. [FOLK_E_00022 / T_02 / c1242] 'Go to the bakery and/in order to buy one.'

\footnotetext{
14 Apart from the use as an emergent purposive marker, there are also uses of kommen und that establish the temporal relation of simultaneity (see Proske 2017). These cannot be discussed here, and they are not specific for kommen, but exist with all V1. These uses do not only have a different function, they also preferably occur with a different set of verbs in the second conjunct (most often stative or mental verbs).

15 For a short discussion of the entrenched status of kommen und sagen in terms of Construction Grammar see Proske (2017).

16 This may be a bias of the FOLK data. Examples without directional adverbial introspectively seem possible.
} 
Second, just as in the case of kommen as V1, the verb in the second conjunct denotes the purpose of the motion event. With gehen being "source-oriented" (Fillmore 1972), however, this event is perspectivized from the view of someone at the source of the motion event, that is, the event is perspectivized as happening at a distant goal.

Third, cases of semantic bleaching only occur when the directional adverbial is hin (directional 'there') or, more rarely in the data, her (directional 'here'), which can also be interpreted as a verb particle. This means that we are actually dealing with a separate verb hingehen ('go there'). Cases of hingehen und show a stronger tendency for semantic bleaching and emergent subjective meaning aspects than kommen und. Cases of gehen with directional PP, in contrast, show no bleaching.

(6) also ich $H A B$ jetz wieder einen, aber ich musste halt HINgehen und sagen ich MÖCHte einen. [FOLK_E_00055 / T_07 / c169]

'I have one [= overdraft limit] again now, but I had to go (there) and say that I want one.'

(7) DU willst den FÜHrerschein. [...] dU krist den NUR, (0.39) wenn du HINgehst, oh und (.) LEIStung zeigst, <<all> indem du dich> HOCHkonzentriert, (0.35) fließend in den verKEHR hineinbringst. [FOLK_E_00146 / T_02 / c203]

'You want a driver's license. You are only going to get it if you go and perform well by concentrating and smoothly taking an active part in the traffic.'

(8) das sind is MEIne philosophie. wenn du jetzt HINgehst-`h und äh äh (0.84) einfach nur draufLOSlebs; [FOLK_E_00261 / T_01 / c61]

'This is my philosophy. If you go (out) and just live for the moment [...]'

Like kommen, (hin)gehen can highlight the effort that is necessary to perform the activity denoted by the verb in the second conjunct, as in (6). It highlights the intentionality in a stronger way than kommen and also conveys a stronger sense of determinedness, as has also been observed for English go and (see e.g. Newman and Lin 2006; Newman and Rice 2008: 18; Stefanowitsch 2000). While (6) may be interpreted as referring to a movement (performed in order to put forward a specific concern), in (7) and (8) this reading is excluded; hingehen only marks purposefulness here. As (8) shows, hingehen can even transfer its purposefulness to non-agentive verbs like leben ('live'), admittedly with the help of the adverb/ particle drauflos ('straight on').

Purposefulness quite often allows or suggests further inferences such as irresponsibility or thoughtlessness, as in (8), where someone who does not live according to a well-thought-out plan, but intentionally 'lives for the moment' 
might be seen as acting thoughtlessly by others. Thus, just as for kommen, there is a tendency towards negatively assessed actions, but this tendency is still far from being a general feature of pseudo-coordination with the two verbs; there are even many clearly positively assessed contexts, as purposefulness also allows positive inferences (such as 'dare'). Still, a tendency towards negative connotations has been observed as well for 'come-say' and 'go-say' constructions (without conjunction) in Finnish conversations (Haddington, Jantunen and Sivonen 2011).

The metaphor PURPOSES ARE DESTINATIONS (Schmidtke-Bode 2009: 98) underlies the emergent use of kommen und and gehen und as markers of purposefulness, which corresponds to the well-known grammaticalization path of morphemes meaning 'go' to purposive markers (see Bybee, Perkins and Pagliuca 1994: 228ff.; Heine and Kuteva 2002: 163-165).

\subsubsection{Change of posture verbs: sich hinsetzen and sich hinstellen}

The two change of posture verbs sich setzen ('sit down') and sich stellen ('stand up') share properties with both the basic motion verbs and the basic posture verbs. Like the motion verbs, they semantically involve an active movement of the subject referent and syntactically have an obligatory directional adverbial. When used in pseudo-coordination, the directional adverbial is hin ('there') in the majority of cases for both verbs ( $77 \%$ for setzen and $71 \%$ for stellen). As, moreover, a bleached semantics only occurs with sich hinstellen und and sich hinsetzen und, this section is restricted to the use of these cases.

In half of the cases, the original semantics of sich hinstellen and sich hinsetzen is preserved, as in (9) and (10) below. Yet, mentioning the change of posture is contextually not necessary; sich hinstellen and sich hinsetzen subjectively frame the activity denoted by the verb in the second conjunct as purposeful or even effortful by highlighting the intentionality, similar to kommen and gehen, that is, they can also be described as "purpose-focusing". Moreover, and in contrast to the motion verbs, the change of posture verbs can in some cases also highlight the temporal extension and non-telicity of the V2 action: The V2 action may already be durative and non-telic, but the implication that this action is performed as long as the subject referent sits or stands strengthens these semantic properties (see (9) and (10)).

(9) ich stell mich an an meinem geburtstag bestImmt net hin und bügel HEMden. [FOLK_E_00024 / T_06 / c366]

'I definitely won't stand up and iron shirts on my birthday.' 
(10) also ich wollte einfach da entSPANnung- wir setzen uns HIN- und halten (0.23) MUND und LUFT an, [FOLK_E_00248 / T_01 / c73]

'I simply wanted relaxation. We sit down and keep our mouths shut and hold our breath.'

The other half of the cases shows semantic bleaching. For sich hinstellen, in most of these cases the V2 is sagen. Sich hinstellen und has an even stronger association with communication verbs than kommen und (see table 1 above). As (11) and (12) show, the underspecified semantics of sagen ('utter') is specified by hinstellen, which adds determinedness. The resulting meaning of sich hinstellen und sagen is 'claim', 'assume the right to judge'.

(11) ich glaube nIcht dass äh- herr GEIßler sich jetz hInstellen wird und SAgen wird; das DARF gebaut werden oder darf NICH gebaut werden. [FOLK_E_00070 / T_09 / c58]

'I don't think that Mr. Geißler will now stand up and say: "This may be built or this may not be built.”"

(12) zwanzig jahre später stellt der staat sich als SCHÜTzer auf. (0.21) stellt sich da oben HIN un sacht ihr DÜRFT dat nich mehr; [FOLK_E_00261 / T_02 / c468]

'Twenty years later the state positions itself as a protector. Stands up, up there, and says: "You are not allowed to do that any more."”

The meaning of sich hinstellen in these cases is extended from the physical to the mental domain: Originally the verb refers to a bodily posture; in its pseudocoordinated use it refers to a "mental posture", that is, a stance. Sich hinstellen und sagen is often used in contexts in which the subject referent of sagen is assessed negatively by the speaker, as in (12), in which a falconer talks about regulations issued by the government which he thinks are hypocritical.

Communication verbs also occur with sich hinsetzen und (see (14)), but the second verb is an activity verb in most cases (see (13)). The meaning of the bleached cases can be described as 'make the effort to x'; in (13) for example, sich hinsetzen und ausrechnen ('sit down and calculate') can be interpreted as 'make the effort to calculate'. Due to the additional highlighting of the temporal extension, the meaning can often also be paraphrased as 'take the time to $x^{\prime}$.

(13) äh des wenn d- wenn einer sich HINsetzt, und das bisschen AUSrechnet, dann fährt er halt möglicherweise LIEber, ${ }^{\circ} \mathrm{h}$ mit der EIsenbahn[FOLK_E_00064 / T_09 / c255]

'If someone sits down and calculates a bit, they may prefer to take the train.' 
(14) denn (.) es is sicher UNgewöhnlich-für ne junge poLItikerin auf dem weg nach Oben, sich so HINzusetzen und zu sAgen- jetz is mal nEt die schnelle SACHverhaltsdurchdrängung, sondern jetz is $\mathrm{mal}^{\circ} \mathrm{h}$ deTAILlwissen- detailABgleich gefragt-[FOLK_E_00069 / T_07 / c413]

'Because it is definitely unusual for a young politician on her way up to sit down [like that] and say: "Now it is not important to understand the issue quickly, but rather to understand details and compare them."'

When used with a communication verb as V2, sich hinsetzen also highlights the determinedness of the communicative event, but - in contrast to sich hinstellen und sagen - it mostly occurs in positively assessed contexts. Thus, in (14) sich hinsetzen und sagen can be paraphrased by 'dare to say/claim'.

Activities for which one has to make the effort to sit down and which are performed while sitting seem to be assessed more positively than activities for which one stands up, possibly because they more clearly imply an extended period of pursuing an activity (often mental work that affords concentration) and therefore are more clearly associated with 'taking the time to do x'. Whether this difference in polarity, observed for a very small set of data, is indeed a general tendency would have to be substantiated on the basis of larger corpora, though. All descriptions of the semantic and collocational tendencies observed for the change of posture verbs have to be regarded as highly preliminary due to the small number of cases.

\subsubsection{Posture verbs: stehen and sitzen}

As observed for the motion verbs, the semantics of the basic posture verbs stehen ('stand') and sitzen ('sit') is clearly bleached in only 10 to $15 \%$ of the pseudocoordinated cases. The local adverbial complement is almost always realized, but in almost half of the cases it is realized by a deictic adverb, especially $d a$ ('there') or, more rarely, hier ('here'), the first of which can in many cases be regarded as a particle belonging to the verb.

Independently of whether sitzen or stehen can be interpreted literally in a concrete instance, their use has several additional semantic effects: The stativity associated with these verbs causes an interpretation of the V2 event as temporally extended. This is true in cases where the second verb denotes an event that could otherwise have a punctual reading (as in (15)) as well as in cases where the second verb already denotes a durative event (as in (16)); the temporal extension is highlighted in all cases. Moreover, even if it is propositionally not necessary to mention the posture in which the subject referent is performing the activity 
denoted by the second verb, the use of the posture verb contributes to the visualization that an utterance may evoke; in (15), for example, the use of und saß $D A$ und dAchte mir (as opposed to und dachte mir alone) evokes a scene of the speaker sitting somewhere (e.g., at home or already at the airport), ${ }^{17}$ doubting her decision to go abroad, as opposed to other possible visualizations, for example, the speaker standing or walking around.

(15) ' hhh ja un dann hatt ich mein TIcket, (0.64) und saß DA un dAchte mir- ahu wAs TUST du. (.) was MACHST du. ${ }^{\circ}$ hh aber dann war_s schon $z u$ SPÄT. [FOLK_E_00257 / T_01 / c592]

'Well, and then I had my ticket and sat there and thought [= and sat there thinking]: "Ahu, what are you doing? What are you doing?”'

(16) und dann KOMMT er nich; so. und dann SITzen wir da und WARten. und dis is ÄTzend. [FOLK_E_00285 / T_02/ c219]

'And then he doesn't show up. And then we sit there and wait [= and then we sit there waiting], and this is God-awful.'

Stehen und functions very similarly to sitzen und in highlighting the temporal extension of the V2 event and contributing to visualization (see (18) below). The choice between the two verbs for this function largely depends on the posture usually taken to perform the V2 activity; for example, while one usually sits when writing, one often stands when doing something in the household. In spite of these differences, the two posture verbs show similar tendencies as far as the verbs and verb classes that appear as V2 are concerned: Like all V1 investigated in this study, they are most often coordinated with activity verbs. Mental verbs and verbs of perception, however, make up a larger part of the verbs in the second conjunct with sitzen and stehen than with all other V1, and communication verbs are rarer as V2 than with all other first verbs. One of the most frequent single second verbs occurring with both sitzen and stehen is warten ('wait'), a verb that does not occur with any of the other first verbs. ${ }^{18}$

A frequent inference associated especially with sitzen und is passivity. This inference arises from the combination of not fully agentive verbs like (sich) denken (used with the meaning 'come to think', 'realize') or warten ('wait') and the durative component contributed by sitzen. The subject referents in examples

17 Whether the speaker was indeed sitting at the time of contemplation is not clear from the context and irrelevant for the understanding of the story told.

18 Newman and Rice (2004: 270) also found this collocation for English (sitting/standing and waiting). 
(15) and (16) are presented as finding themselves in an unchangeable, regrettable situation, either because they experience their own actions as uncontrollable (15) or because external agents put them in an unpleasant situation (16). ${ }^{19}$ The association with passivity is not always negatively assessed (e.g. wir ham da geSESsen und ZEItung gelesen. FOLK_E_00220 / T_02 / c234, 'we sat there reading the paper') and still very much contextually driven. With V2 that have more agentive semantics we also find associations with the opposite of passivity, that is, with extended activity. This can lead to inferences like diligence, as in (17).

(17) ${ }^{\circ} \mathrm{h}$ ich hab halt kEInen nerv AUFzuräum im moment. (1.16) weil ich halt da immer nur SITZE- un irgendwas SCHREIbe oder LERne, [FOLK_E_00321 / T_02 / c1126]

'I am not motivated to tidy up at the moment because I always sit there and write or learn something [ = because I am writing or learning all the time].'

Such examples associated with extended activity most clearly show the potential of sitzen und to give rise to progressive aspect, as they have dynamic, agentive verbs in the second conjunct, which are marked as ongoing by the durativity inherent to the posture verb. It is an interesting question whether in case of (further) grammaticalization non-dynamic second verbs like the one in (15) would no longer be usable with sitzen und or whether we are dealing with incipient continuous aspect from the start, which would be unusual as continuous aspect is said to develop out of progressive aspect (see Bybee, Perkins and Pagliuca 1994; Comrie 1976; Hesse 2009).

Two observable tendencies set the use of stehen und apart from the use of sitzen und: First, it is compatible with a habitual interpretation of a V2 activity, as in (18) below. The subject referent in this example is said to observe (beobachten) people in a bar and to do so for an extended period of time (stehen und beobachten). The habitualness is coded by the temporal adverbial abends ('in the evenings'), that is, it is still the verbal context, not the V1 alone, that evokes a habitual reading. What is interesting is that no habitual interpretations of sitzen und were found in the data. This may either be a genuine difference in use or a bias of the small database.

(18) der redet normalerweise mit NIEmandem. der steht-abends in der bAr steht der DA, un beObachtet. [FOLK_E_00046 / T_02 / c559]

'And he normally doesn't talk to anyone. In the evening at the bar, he stands there and observes.'

19 Newman and Rice (2004: 273ff.) also found for English that passivity and a potentially negatively assessed "extended inactivity" are associated with sit (around) and stand (around). 
Second, while both verbs are used in pseudo-coordination with communication verbs, only the cases of stehen und plus communication verb are used with the meaning 'express a concern/an opinion' that was also found for the motion verbs and the change of posture verbs, as (19) shows. This might be a bias of the small database, but seems plausible semantically: To stand somewhere is the result of a movement made with a purpose (coming, going, standing up), so at the moment of utterance someone may be standing somewhere expressing a concern. It seems introspectively rarer for someone to sit down in order to express a concern, although there are examples of this (see (14)). If someone 'sits and says' something, however, they are, according to the data, more rarely expressing a concern than merely telling a story or chatting with others, highlighting the temporal extension.

(19) un ich will nich dass mein kInd mal mit irgenwie (0.28) sEchzehn Achtzehn zwAnzig DAsteht und- 'hh mir sagt jA du hast DEUTSCH studiert, du hast dort geLEBT, und hast es mir nich BEIgebracht. [FOLK_E_00257 / T_02 / c918] 'And I don't want my child to stand there at sixteen, eighteen, twenty years old and say: "Well, you studied German, you lived there, but you didn't teach it to me.”"

As for sitzen und, there are a couple of examples of stehen und in the data that show the potential for progressive aspect to grammaticalize out of pseudocoordinated uses. The speaker of (20) tells her friends how she was already late when picking up a friend and that friend (Myrte) was still blow-drying her hair when she arrived to pick her up. The use of stehen again highlights the temporal extension of sich die Haare föhnen ('blow-dry one's hair'); while the second verb alone would have allowed the interpretation that the subject referent was just finishing the action, the pseudo-coordination hints at both the action being in progress and the "mental posture" of the subject referent, who is depicted as not aware of the pressure of time and performing the action placidly.

(20) und myrte STEHT dann da- und FÖHNT sich die hAAre als ich komme. [FOLK_E_00267 / T_01 / c810]

'And Myrte stands there and blow-dries her hair when I come' / 'And Myrte is blow-drying her hair when I come.'

The findings for the posture verbs are in line with cross-linguistic tendencies: "Habituality and progressivity frequently develop out of basic postural senses" (Newman and Rice 2004: 353; see also Heine and Kuteva 2002: 193f., 276ff., 280ff.). As for English sit and stand, the inference of "extended duration" (Newman and Rice 2004: 370) has not yet been grammaticalized in German as it has in the Scandinavian languages (Hesse 2010), but it is one conventionalized reading. 


\subsubsection{Nehmen und}

The transfer verb nehmen ('take') used in pseudo-coordination differs in two ways from the V1 discussed so far. First, it is a transitive verb, that is, the first conjunct always involves a direct object, the referent of which is picked up by a pronoun in the second conjunct, which usually involves a transitive verb as well. Second, while nehmen shows semantic bleaching in a third of the pseudo-coordinated cases, it has not (yet) developed any new, subjective meaning components. Rather, it is primarily used for packaging information and verbal actions in a way that accommodates the contingencies of spontaneously spoken language.

(21) und dU nimmst die zwei TAschen da? (0.6) und tust die: (0.35) in die Ecke da wo der SPIEgel is? [FOLK_E_00217 / T_01 / c1379]

'And you take these two bags over there and put them into the corner where the mirror is.'

(22) und du kannst dir (0.2) n TISCH suchen, (.) n FREIen, und dir JEdes spiel nehmen und mal AUSprobieren. [FOLK_E_00273 / T_04 / c117]

'And you can choose an empty table and take any game and try [it] out [= and take and try out any game].'

(23) der nimmt ja auch die wirklich die texte seines VAters- und und arbeitet dann DIE genau- also der NIMMT die- und arbeitet sich an DEnen ab. [FOLK_00058 / T_01 / c1216]

'He really takes his father's texts and works them- he takes them and and exhausts them.'

As examples (21)-(23) show, in both literal and non-literal uses of nehmen, a new referent is introduced as the direct object. The propositionally relevant verb is then realized in the second conjunct. In all cases, this could have been accomplished in a single clause, that is, with a single verb. For example, the request to take two bags and put them in a corner in (21) could have been verbalized as du tust die zwei Taschen da in die Ecke ('you put the two bags over there into the corner'). Instead, the speaker of (21) uses separate clauses for the introduction of a new referent and the mentioning of the requested action, thereby 'chunking' the new information. This can be seen as facilitating the production and reception processes occurring in real time.

The object referent of nehmen is almost always new, that is, has not been mentioned before in the discourse, and the verb in the second conjunct is almost always 'contentful', that is, semantically quite specific, as opposed to underspecified general activity verbs such as machen ('make'). The information 
packaging effect can be achieved with other first verbs in a pseudo-coordination as well, but it is considerably rarer with the other $\mathrm{V}^{20}$ (see section 4).

Even though the information packaging effect is so prominent for nehmen und, it is not the only motivation for its use; its semantics also play a role. Like the other fist verbs discussed so far, nehmen is an extremely frequent, polysemous verb. Unlike these basic motion and posture verbs, however, it can be used in pseudo-coordination in several of its meanings. The motion and posture verbs are used in pseudo-coordination either in their basic, physical sense or are desemanticized, but have acquired subjective meanings that the verbs do not cover in non-pseudo-coordinated uses. Nehmen, in contrast, appears in pseudocoordination with its literal, physical sense 'take' (see (21) and (22)) as well as with more abstract senses that are also listed in dictionaries; the meaning in (23), for example, can be paraphrased as 'use (as an example)'. All cases that have one of the non-literal meanings have been counted as 'bleached'.

The meaning 'use (as an example)' lends itself to uses in contexts of exemplification, as found in instructions and argumentations, as in (23). Both the information packaging function and the tendency to be used in contexts of giving examples have been observed by Hopper $(2002,2008)$ for the English equivalent, take and, as well. Both the English and the German construction are still far away from the Scandinavian equivalents of 'take', which have developed into inchoative markers and lost their direct object in the process (see Hesse 2010).

\section{Discussion: Discourse motivations and grammaticalization}

As pointed out, the information packaging function that is always present when nehmen und is used can also be found for all other V1 in pseudo-coordination, in cases with bleached semantics as well as in cases with literal meanings, as in the following examples.

20 A third of the subjects of kommen and stehen and a fourth of the subjects of sitzen are new referents, while almost none of the subjects of gehen, setzen and stellen are new. More that half of the obligatory adverbials of gehen, stehen and sitzen contain new referents, but only up to a fourth of the adverbials of stellen, kommen and setzen. 
(24a) ja wenn jetz $n$ WAHLabonnent kOmmt un will ((die kompletten oratorien)) ham, hat er bisher immer AUFzahlen müssen. [FOLK_E_00082 / T_01 / c43]

'If a subscriber comes and wants to have the complete oratories, he used to have to pay more.'

(24b) Wenn ein Wahlabonnent die kompletten Oratorien haben will, ... 'If a subscriber wants to have the complete oratories, ...'

(25a) sich so auf den rÜcken richtig viel finalGON- und dann zum maSSEUR gehn und es ihm nich SAgen. [FOLK_E_00208 / T_02 / c510]

'[put] a lot of Finalgon onto your back and then go to the masseur and don't tell him.'

(25b) ... und es dem Masseur nicht sagen.

'... and not tell the masseur about it.'

In (24a) kommen und is used to introduce one new referent per clause, one as the subject of kommen (Wahlabonnent) and the other one as the direct object of haben ('have') (Oratorien). This way, it is avoided that the two referents are introduced within a single clause like (24b). Pseudo-coordination thus adheres to the well-known tendency for clauses (or other 'chunks' such as intonation units) in spontaneously spoken language to contain at most one new piece of information, which is motivated by the constraints of working memory (see e.g. Chafe 1994). The use of gehen und in (25a) allows for a new referent (Masseur) to be introduced within the directional adverbial of gehen and thus separately from the negated V2 sagen. This also facilitates the accentuation of both Masseur and sagen in separate intonation units. Moreover, using the structures in (24a) and (25a) avoids possible alternatives like (24b) and (25b), in which new referents would be introduced in argument roles that have been empirically shown to be dispreferred for this function - as the subject of a transitive verb (24b) or as an indirect object (25b) (Du Bois 2003).

Pseudo-coordination also builds on the preference in spontaneous discourse for using semantically unspecific verbs for introducing new referents and predicating something about them in the next clause with lexically more specific verbs (see Proske 2013). It is a conventionalized construction for this function, and its recurrence allows for new semantic and pragmatic inferences to become gradually conventionalized as well and this may ultimately give rise to the grammaticalization of frequent V1.

Currently, the degree of grammaticalization is low for the German pseudocoordination construction(s): The bleaching of V1 and the use of aspectual or subjective meaning components are still optional despite the monopredicativity 
that all cases share. The rarity of clearly bleached instances is also reflected in the finding that it is still possible to prosodically separate the first and second conjunct and to accentuate the V1; as Barth-Weingarten and Couper-Kuhlen (2011) have shown for English, a stronger monopredicativity is associated with more frequent prosodic 'integration' (i.e., the realization of both conjuncts within one intonation unit).

Moreover, it is still possible for intervening elements to occur between the verbs and the conjunction. Intervening elements occur equally frequently with clearly bleached V1 as with non-bleached V1. They are, however, less frequent with sagen as V2. This is true for all V1, but the effect is especially strong for kommen und sagen; in 54\% of all cases of kommen und sagen no or one word occurs between kommen and the conjunction as well as between the conjunction and sagen, for the other V2 the percentage lies between 33 and 45 .

What also speaks for a low degree of grammaticalization is the possibility of an overtly realized (pronominal) subject in the second clause for all V1, with the same monopredicative effect. No such examples could be adduced here, but have been discussed for kommen und by Proske (2017). Such cases also show that there is no one-to-one correspondence between form and function yet.

Still, as shown in the present study, aspectual and subjective meaning components are emerging for pseudo-coordination in German. These components have been cross-linguistically observed in the context of the grammaticalization of first verbs in pseudo-coordination. Moreover, the two clauses are not independent; the first one is semantically-pragmatically dependent, the second one syntactically. Thus, the V1 is already losing its status as a lexical verb (without becoming an auxiliary); it is increasingly used because of its potential to focus the V2. While the non-subject complement of the first verb is still often realized, the large amount of semantically bleached adverbs among these complements, which are interpretable as verb particles (hingehen, dastehen), also allows the interpretation that the first conjunct is already formally reduced quite often.

Relating these observations to the discussion of discourse motivations for the use of pseudo-coordination above, it can be hypothesized that the information packaging effect is greater the lower the degree of grammaticalization is: The further a pseudo-coordination construction is grammaticalized, the more 'compact' it is; the loss of the originally obligatory non-subject complement means that there is one opportunity less for introducing a new referent, and with less intervening elements between the verbs and the conjunction and a more frequent integrated prosodic realization, there will be less prosodic 'chunking', too. Moreover, the increase in subjective semantics makes the construction less likely to be used for introducing a new referent in the subject role as well, because the first verb is not 'neutral' any more; therefore, when using it for introducing a 
new referent, it at the same time already assesses that referent, which combines two verbal actions that are preferentially performed in separate clauses (see e.g. Couper-Kuhlen and Thompson 2008).

This hypothesis is corroborated by the finding that nehmen und is used for referent introduction much more frequently than the other verbs investigated in this study, which show more signs of subjectification and grammaticalization. Moreover, even more clearly subjectified and grammaticalized pseudocoordination constructions in other languages, such as English go and and the various Scandinavian constructions, have not often been investigated for their discourse functions, as their main function is a semantic or even grammatical one, that is, it is often not possible to use it for information packaging at all. In contrast, less subjectified and grammaticalized constructions, such as English take and or turn around, have been the subject of discourse-functional studies. Of course, this is all a matter of degree and the constructions with stronger semantic functions can also often still be used for discourse-related functions; as long as the original semantics are not completely bleached, it can be evoked for visualizations and related functions (see Hesse 2009 for Norwegian sitte og and stå og) and can play a role in information packaging. Still, the tendency towards a 'tradeoff' between semantic-pragmatic functions with clausal scope and discourse-pragmatic functions with broader scope is clear and is in line with grammaticalization theory.

\section{Conclusion and outlook}

The present paper has given a very coarse overview over emergent pseudocoordination in spoken German and focused on its grammaticalization potential. The interpretations of the directions of semantic change of the different V1 will have to be substantiated in more detailed verb-specific studies. These should include analyses of prosodic factors and further co-occurences (e.g modal particles or adverbs, temporal adverbials, negatively or positively connotated elements). Moreover, the turn-constructional and sequential contexts, which have so far only been analyzed for kommen, could reveal a finer functional distinction between the verbs. Finally, other potential V1 should be investigated (e.g., rumlaufen, 'walk around'; anfangen, 'begin'; sein, 'be') as well as the phenomenon of asymmetric coordination in general, that is, independently of the lexemes used most frequently in this construction, as it does not seem to be restricted to these. Clause-combinations with coordinating conjunctions that are used for subordinating semantic relations (e.g., causal or final) have not 
systematically been studied in their use in spontaneous spoken German; they involve several semantic, pragmatic und syntactic properties that are worth investigating.

\section{References}

Barth-Weingarten, Dagmar and Elizabeth Couper-Kuhlen. 2011. Action, prosody and emergent constructions: The case of and. In Peter Auer and Stefan Pfänder (eds.), Constructions emerging and emergent, 263-292. Berlin: de Gruyter.

Bybee, Joan L., Revere D. Perkins and William Pagliuca. 1994. The evolution of grammar: Tense, aspect and mood in the languages of the world. Chicago: The University of Chicago Press.

Chafe, Wallace. 1994. Discourse, consciousness, and time: The flow and displacement of conscious experience in speaking and writing. Chicago: The University of Chicago Press.

Comrie, Bernard. 1976. Aspect. An introduction to the study of verbal aspect and related problems. Cambridge: Cambridge University Press.

Couper-Kuhlen, Elizabeth and Sandra A. Thompson. 2008. On assessing situations and events in conversation: "extraposition" and its relatives. Discourse Studies 10. 443-467.

Di Meola, Claudio. 1994. Kommen und gehen. Eine kognitiv-linguistische Untersuchung der Polysemie deiktischer Bewegungsverben. Tübingen: Niemeyer.

Du Bois, John W. 2003. Argument structure: Grammar in use. In John W. Du Bois, Lorraine E. Kumpf and William J. Ashby (eds.), Preferred Argument Structure. Grammar as architecture for function, 11-60. Amsterdam: Benjamins.

Fillmore, Charles J. 1972. How to know whether you're coming or going. In Karl HyldgaardJensen (ed.), Linguistik 1971. Referate des 6. Linguistischen Kolloquiums 11.-14. August in Kopenhagen, 369-379. Frankfurt a.M.: Athenäum.

Haddington, Pentti, Jarmo H. Jantunen and Jari Sivonen. 2011. Language and affect: Go-say and come-say constructions in Finnish. Sky Journal of Linguistics 24. 75-117.

Heine, Bernd and Tania Kuteva. 2002. World lexicon of grammaticalization. Cambridge: Cambridge University Press.

Hesse, Andrea 2009. Zur Grammatikalisierung der Pseudokoordination im Norwegischen und in den anderen skandinavischen Sprachen. Tübingen: A. Francke Verlag.

Hilpert, Martin and Christian Koops. 2008. A quantitative approach to the development of complex predicates. The case of Swedish Pseudo-Coordination with sitta 'sit'. Diachronica 25(2). 240-259.

Hopper, Paul J. 2002. Hendiadys and auxiliation in English. In Joan Bybee and Michael Noonan (eds.), Complex sentences in grammar and discourse. Essays in honor of Sandra A. Thompson, 145-173. Amsterdam: Benjamins.

Hopper, Paul. 2008. Emergent serialization in English: Pragmatics and typology. In Jeff Good (ed.) Linguistic universals and language change, 253-284. Oxford: Oxford University Press.

Langacker, Ronald. 1990. Subjectification. Cognitive Linguistics 1(1). 5-38.

Lehmann, Christian. 1991. Grammaticalization and related changes in contemporary German. In Elizabeth C. Traugott and Bernd Heine (eds.), Approaches to grammaticalization. Vol. II: Focus on types of grammatical markers, 493-535. Amsterdam: Benjamins. 
Newman, John and Jingxia Lin. 2006. The purposefulness of going: A corpus-linguistic study. In Jacek Walinski, Krzysztof Kredens and Stanislaw Gozdz-Roszkowski (eds.), Practical applications in language and computers 2005 proceedings, 293-308. Frankfurt am Main et al.: Peter Lang.

Newman, John and Sally Rice. 2004. Patterns of usage for English SIT, STAND, and LIE: A cognitively inspired exploration in corpus linguistics. Cognitive Linguistics 15(3). 351-396.

Newman, John and Sally Rice. 2008. Asymmetry in English multi-verb sequences. A corpusbased approach. In: Barbara Lewandowska-Tomaszczyk (ed.), Asymmetric events, 3-23. Amsterdam: Benjamins.

Proske, Nadine. 2013. Informationsmanagement im gesprochenen Deutsch. Eine diskurspragmatische Untersuchung syntaktischer Strukturen in Alltagsgesprächen. Heidelberg: Winter.

Proske, Nadine. 2017. Perspektivierung von Handlungen und Zuschreibung von Intentionalität durch pseudokoordiniertes kommen. In Arnulf Deppermann, Nadine Proske and Arne Zeschel (eds.), Verben im interaktiven Kontext. Bewegungsverben und mentale Verben im gesprochenen Deutsch, 177-247. Tübingen: Narr.

Ross, Daniel. 2013. Verbal Pseudocoordination in English: A syntactic analysis with reference to diachronic, dialectal and cross-linguistic variation. Manuscript. https://www.ideals. illinois.edu/handle/2142/42581 (15 March, 2019).

Schmidtke-Bode, Karsten. 2009. A typology of purpose clauses. Amsterdam: Benjamins.

Selting, Margret et al. 2009. Gesprächsanalytisches Transkriptionssystem 2 (GAT 2). Gesprächsforschung - Online-Zeitschrift zur verbalen Interaktion 10. 353-402.

Stefanowitsch, Anatol. 2000. The English GO-(PRT)-AND-VERB construction. Berkeley Linguistics Society (BLS) 26. 259-270.

Traugott, Elizabeth C. and Richard B. Dasher. 2002. Regularity in semantic change. Cambridge: Cambridge University Press. 